\title{
Sustainability of Farmer Producer Organisations - The case of producer organisations involved in the production and marketing of 'neera' in the coconut sector in Kerala, India
}

\author{
C. Thamban, S. Jayasekhar *, K.P. Chandran and M.K. Rajesh \\ ICAR-Central Plantation Crops Research Institute, Kasaragod-671124, Kerala, India
}

(Manuscript Received: 12-05-2020, Revised: 06-07-2020, Accepted: 11-07-2020)

\begin{abstract}
Neera - the coconut inflorescence sap has been promoted as a potential value-added non-alcoholic beverage with abundant health benefits. The concerted effort of the stakeholder agencies could liberate the product from the policy regulations on its production under the excise act (known as 'Abkari act' in Kerala). Subsequently, the coconut producer federations (CPFs) in the State were granted licenses for 'neera' production and marketing. However, the majority of the CPFs discontinued the 'neera' enterprise, which they have initiated with greater enthusiasm. The present study is a modest attempt to trace the reasons for setbacks experienced in the 'neera' sector and also to provide a refined framework for revamping the sector. The details of licenses granted to the CPFs were sourced from the Department of Excise, Government of Kerala. The sample size of the study was 95 (13 CPFs who are still active and $82 \mathrm{CPFs}$ who have discontinued). It was observed that the 'neera' value chain is in the evolving stage, and the withdrawal of the institutional support had detrimentally affected the confidence of the CPFs ventured into it. The availability of 'neera' technicians (tappers) and the high wage rates have evoked concerns on the profitability as well as the assurance of continuous supply of the product. The study categorically highlights the need for a restructured value chain of 'neera' with specific roles assigned to the stakeholders through the creation of functional linkages.
\end{abstract}

Keywords: Coconut sector, neera, sustainability

\section{Introduction}

Indian agrarian system is dominated by smallholder farming, where the average size of farm holdings is only 1.08 ha (Gulati and Juneja, 2019). Of the total holdings, 85 per cent are in marginal and small farm categories of less than two hectares. By organizing small and marginal farmers into farmer groups and Farmer Producer Organizations (FPOs), they will have better access to technical knowhow on crop planning and management, inputs, credit, post-harvest management, value addition, marketing infrastructure and market linkages. During the last few decades, a wide range of farmer organizations have emerged as part of the agricultural innovation systems, and their number is on the rise (Hellin and Camacho, 2017).Several empirical studies have highlighted the role played by such organizations across the world in promoting the socio-economic betterment of the farmers. They are viewed as the only institutions which can protect small farmers from ill-effects of globalization or make them participate successfully in modern competitive markets (Lijo et al., 2017; Trebbin, 2014; Trebbin and Hassler, 2012).

Presently coconut growers are more exposed to economic risks and uncertainties owing to the high degree of price fluctuations (Jayasekhar et al., 2019). Coconut is cultivated predominantly in small and marginal holdings, and farmers face serious limitations to effectively utilize technologies for realizing higher productivity and income from such tiny holdings. The potential for promoting group

*Corresponding Author: jaycpcri@gmail.com 
management approach among small and marginal coconut farmers to overcome their resource limitations and to enhance productivity and income from farming has been amply demonstrated under the action research programmes implemented by ICAR-Central Plantation Crops Research Institute (Thamban et al., 2016a). The Coconut Development Board (CDB) has been promoting the formation of FPOs in the coconut sector. The primary objective of mobilizing coconut farmers into member-owned producer organizations is to improve productivity and promote product diversification and marketing for enhancing the profitability of coconut farming (Jnanadevan, 2016). Value addition through product diversification is an important strategy suggested for enhancing coconut farmers' income.

However, in the coconut sector, the extent of value addition is very low, and the price of coconut is mostly decided by the conventional products; copra and coconut oil. The coconut inflorescence sap, namely 'neera', is a value-added product with huge potential to be promoted as a health drink. Technologies for extracting 'neera' from coconut palms were developed by various research institutions, including ICAR-CPCRI (Hebbar et al., 2015). Even though 'neera' is a 'zero alcohol' drink, its production and marketing were restricted due to the provisions of the 'Abkari Act' governing the production and marketing of alcoholic beverages prevailing in the major coconut producing States: Kerala, Karnataka, Tamil Nadu and Andhra Pradesh. However, due to the concerted efforts of CDB and coconut growers' associations, the Government of Kerala amended the 'Abkari Act' and created a congenial policy environment for the production and marketing of 'neera' by selected agencies including Coconut Producers' Federations (CPFs) affiliated to CDB. It was a historic governmental initiative to support coconut growers through a pro-farmer policy. Subsequently, governments of Tamil Nadu and Karnataka also amended the existing acts, and FPOs in the coconut sector were granted permission for the production and marketing of 'neera'. Encouraged by the favourable policy environment and incentives, many coconut FPOs established 'neera' production units in their respective jurisdictions and started its marketing. Licenses were granted to CPFs in Kerala to produce and market 'neera' within the initial three years of issuing the government order. However, reports from the sector indicate that a substantial number of 'neera' units managed by CPFs were discontinued due to various constraints (Thamban et al., 2016b). It is worthwhile to analyze the present scenario of producer organizations involved in the production and marketing of 'neera' in the coconut sector for evolving strategies to revamp the sector.

In this backdrop, the present study was conducted to analyze (i) the status of FPOs in coconut sector (ii) the evolution of policy environment to facilitate 'neera' production and marketing (iii) the field level scenario of sustainability of interventions on 'neera' taken up by CPFs and (iv) the desired structure of support mechanism to enable FPOs to sustain the 'neera' enterprise.

\section{Analytical frame}

Both primary and secondary data were used for analysing the specific objectives of the study. The study was conducted in Kerala since it was the Government of Kerala who amended the 'Abkari Act' for the first time in the country to enable CPFs affiliated to CDB for the production and marketing of 'neera'. Primary data on production, marketing and perceptions on 'neera' were collected from 95 respondents (CPFs) using an interview schedule. The respondents include $13 \mathrm{CPFs}$ who are continuing the 'neera' enterprise and $82 \mathrm{CPFs}$ who have discontinued the activities. In-depth interviews were conducted with Presidents of the CPFs to gather a detailed account of the functioning of CPFs, and the activities concerning production and marketing of 'neera'. Secondary data on the evolution of policy frame on 'neera' and the details of licenses issued were collected from the Department of Excise, Government of Kerala. Exclusive case studies were also conducted on three selected 'neera' units managed by coconut FPOs in the State. General information regarding the status of FPOs in the coconut sector, especially the threetier structure of the organization of FPOs was collected from the CDB.

\section{Farmer Producer Organizations in the coconut sector}

Organizing the unorganized coconut sector through farmer's collectives was one of the 
important activities of $\mathrm{CDB}$ during the twelfth Five-Year Plan. Since then, $\mathrm{CDB}$ has been facilitating the formation and handholding of FPOs in the coconut sector. The three-tier FPO structure facilitated by the board has coconut farmers organized into small neighbourhood informal groups at grass root level as Coconut Producer Societies (CPSs) which are small scale FPOs formed by an association of 40-100 coconut growers in a contiguous area with a consolidated minimum of 4000-5000 palms. The farmer member contributes equity in the organization and undertakes activities aimed at productivity improvement, cost reduction, collective marketing, processing and product diversification. The CPS forms the basic unit of the FPO framework in the sector. The next hierarchical tier, the CPF is formed by combining about 8-10 CPSs. The FPOs formed are provided legal status through registration under the Charitable Societies Act and are also registered with CDB. An aggregation of 8-10 CPFs would form a Coconut Producer Company (CPC). A CPC will have around 10 lakh coconut palms under its management. These companies, fully owned by the farmers, are registered under section 581B of Indian Companies Act of 1956. So far, 9736 CPSs, 743 CPFs and 67 CPCs have been registered in the country. The progress of CPS, $\mathrm{CPF}$ and $\mathrm{CPC}$ formation so far is summarised in Table 1.

Table1. Progress of Coconut Producers' Society, Federation and Company formation

\begin{tabular}{llccc}
\hline $\begin{array}{l}\text { Sl. } \\
\text { No. }\end{array}$ & States & $\begin{array}{c}\text { No. of } \\
\text { CPS }\end{array}$ & $\begin{array}{c}\text { No. of } \\
\text { CPF }\end{array}$ & $\begin{array}{c}\text { No. of } \\
\text { CPC }\end{array}$ \\
\hline 1. & Kerala & 7226 & 467 & 29 \\
2. & Tamil Nadu & 665 & 69 & 17 \\
3. & Karnataka & 400 & 125 & 13 \\
4. & Andhra Pradesh & 1148 & 82 & 8 \\
5. & West Bengal & 216 & - & - \\
6. & Odisha & 39 & - & - \\
7. & Assam & 27 & - & - \\
8. & Gujarat & 14 & - & - \\
9. & Maharashtra & 01 & - & - \\
\hline & Total & 9736 & 743 & 67 \\
\hline
\end{tabular}

Source: Coconut Development Board (2020)

\section{Evolution of policy on 'neera' production and marketing}

Development of technologies for the production of 'neera' from coconut palms, awareness about its potential as a health drink and economic benefits lead to the widespread discussion at the policy level on creating an enabling environment to support coconut growers to utilize the potential of 'neera', who were otherwise struggling due to low market price of coconut. The CDB made efforts to convince the State governments on the need to support the coconut farming community to utilize the potential of 'neera'.Various farmer organizations also pressurized the State government to amend 'Abkari Act' to enable coconut growers to take up enterprises for production and marketing of 'neera' for enhancing income from coconut farming.

Meanwhile, efforts of the Government of Kerala to save the traditional 'toddy' sector, which was going through a crisis, also indirectly contributed for the evolution of a congenial policy environment to support coconut growers for 'neera' production. 'Toddy' is the traditional alcoholic drink produced by tapping unopened coconut inflorescence and the sector provides employment opportunities to a substantial number of skilled palm climbers and benefitted coconut growers who were providing palms for toddy tapping on lease which fetched them more income compared to selling coconuts. The Excise Department regulated the production and marketing of toddy as per the provisions of the 'Abkari Act'. Labour problems, lack of availability of the sufficient number of palms for tapping and market constraints had adversely affected the toddy sector and a crisis developed in the sector. Hence, the Government of Kerala constituted an expert committee in the year 2013 to study the situation in toddy sector and to assess the potential for production and marketing of 'neera' as an alternative strategy to solve the crisis in the sector. The expert committee with the Excise Commissioner as Chairman submitted the report on $18^{\text {th }}$ May 2013. Major recommendations of the committee include (i) amendment of the existing 'Abkari Act' to facilitate 'neera' production and marketing with a regulatory mechanism under 
Excise Department (ii) grant permission for CPSs/ CPFs facilitated by CDB to start more than one 'neera' production units in Thiruvananthapuram, Kollam and Pathanamthitta districts and one 'neera' unit each in all the remaining districts in the State on trial basis (iii) give priority for palm climbers in 'toddy' sector for tapping coconut palms for 'neera' production; if sufficient skilled climbers are not available, organize training programme to train 'neera' technicians and enrol them in 'toddy' tappers welfare fund and (iv) establish a Toddy-Neera Board for the development of the sector.

The government accepted the recommendations of the expert committee and issued orders (G.O. (MS) No. 17/2014/Taxes Department, Thiruvananthapuram dated 03.02.2014) for implementing the recommendations. Amendments were made to the existing 'Abkari Act' of 1931 (Notification No. 26 dated 22 ${ }^{\text {nd }}$ August 1931 published in the Cochin Gazette dated $6^{\text {th }}$ Chingam 1107) and rules (Kerala Sweet Toddy (Neera) Rules 2014) were framed for issuing licenses for the production and marketing of 'neera' to CPSs/CPFs and five other agencies (G.O. (P) No.27/2014/Taxes Department, Thiruvananthapuram dated 14.02.2014).
The Toddy-Neera Board was also established through a government order (G.O. (MS) No.66/ 2014/Taxes Department, Thiruvananthapuram Dated 13.05.2014) with Agricultural Production Commissioner as the Chairman and Excise Commissioner as the Chief Executive Officer for implementing suitable interventions to make coconut farming more remunerative and to promote marketing of 'neera' as a health drink within the State and other parts of the country.

Government of Kerala took many steps to promote 'neera' production as an important measure to solve the problems in the coconut sector. A substantial amount was set apart for this purpose in the budget for 2015-16 by the Government. Support components proposed in the budget included subsidy for the training of 'neera' technicians, support for CPCs for the installation of plant and machinery for 'neera' production, and providing equity support to the coconut FPOs.

Efforts were made by the Government to ensure that licenses were given to all CPSs/CPFs affiliated to CDB who gave application for the license to produce and market 'neera'. Further, it was decided to give license to KERAFED, the apex co-operative federation of coconut farmers in Kerala also for the

Table 2. Scenario of CPFs on production and marketing of 'neera' in Kerala State as on $1^{\text {st }}$ January 2020

\begin{tabular}{|c|c|c|c|c|c|}
\hline $\begin{array}{l}\text { Sl. } \\
\text { No. }\end{array}$ & District & $\begin{array}{c}\text { CPFs with the } \\
\text { licenses for 'neera' } \\
\text { production }\end{array}$ & $\begin{array}{c}\text { CPFs started } \\
\text { 'neera' } \\
\text { production }\end{array}$ & $\begin{array}{c}\text { CPFs discontinued } \\
\text { 'neera' } \\
\text { production }\end{array}$ & $\begin{array}{c}\% \text { of } \\
\text { discontinuance }\end{array}$ \\
\hline 1. & Thiruvananthapuram & 10 & 6 & 6 & 100 \\
\hline 2. & Kollam & 3 & 3 & 2 & 66 \\
\hline 3. & Alappuzha & 17 & 9 & 9 & 100 \\
\hline 4. & Pathanamthitta & 1 & 1 & 1 & 100 \\
\hline 5. & Kottayam & 6 & 3 & 2 & 66 \\
\hline 6. & Idukki & 2 & 1 & 1 & 100 \\
\hline 7. & Ernakulam & 11 & 8 & 4 & 50 \\
\hline 8. & Thrissur & 6 & 3 & 2 & 66 \\
\hline 9. & Palakkad & 11 & 10 & 9 & 90 \\
\hline 10 & Malappuram & 56 & 9 & 9 & 100 \\
\hline 11. & Kozhikode & 58 & 35 & 30 & 86 \\
\hline 12. & Wayanad & 1 & 1 & 1 & 100 \\
\hline 13. & Kannur & 13 & 4 & 4 & 100 \\
\hline 14. & Kasaragod & 9 & 2 & 2 & 100 \\
\hline & Total & 204 & 95 & 82 & 86 \\
\hline
\end{tabular}

Source: Collected from Department of Excise, Kerala (District level) 
Table 3.CPFs perception $(n=82)$ on discontinuance of 'neera' production

\begin{tabular}{|c|c|c|c|}
\hline $\begin{array}{l}\text { SI. } \\
\text { No. }\end{array}$ & Factors contributing to the discontinuance & Type of factor & $\begin{array}{c}\text { No. and per cent } \\
\text { of CPFs citing } \\
\text { the factor }\end{array}$ \\
\hline 1. & Scarcity and high wage rate of palm climbers/ 'neera' technicians & Labour & $48(59)$ \\
\hline 2. & Marketing problems & Marketing & $45(55)$ \\
\hline 3. & Lack of continued support from CDB & Institutional support & $32(39)$ \\
\hline 4. & Low economic viability & Economic viability & $28(34)$ \\
\hline 5. & Problems in tapping palms during the rainy season & Technology & $23(28)$ \\
\hline 6. & Low yield of 'neera' due to poor management of coconut palms & Technology & $22(27)$ \\
\hline 7. & Inadequate support from state government agencies/LSGs & Institutional support & $21(26)$ \\
\hline 8. & $\begin{array}{l}\text { Drudgery involved in climbing palms for tapping due to predominance } \\
\text { of very tall coconut palms }\end{array}$ & Labour & $12(15)$ \\
\hline 9. & $\begin{array}{l}\text { Lack of product uniformity due to non-standardized technologies for } \\
\text { 'neera' production }\end{array}$ & Technology & $9(11)$ \\
\hline 10. & Spoilage due to low keeping quality of 'neera'. & Technology & $9(11)$ \\
\hline 11. & $\begin{array}{l}\text { CPC not formed in the area of CPF functioning to manage the } \\
\text { marketing of 'neera.' }\end{array}$ & Institutional support & $3(4)$ \\
\hline 12. & Inadequate processing facilities & Institutional support & $3(4)$ \\
\hline
\end{tabular}

Note: Figures in parentheses are in percentages

production and marketing of 'neera'. The number of coconut palms a CPS or CPF can use for tapping 'neera' was enhanced from 1500 to 5000 (G.O. (MS) No.111/2015/Agriculture, Thiruvananthapuram Dated 25.06.2015).

\section{Field level scenario of sustainability of 'neera' sector}

The data from district offices of State Excise Department revealed that a total of 204 CPFs were granted licenses to produce and market 'neera'. Most (91\%) of these licenses were issued during the period from 2014 to 2016 . Only 95 (43\%) CPFs initiated the production activities. The remaining CPFs could not initiate 'neera' production mainly due to the lack of skilled palm climbers and lack of 'neera' processing plant under the CPCs in their jurisdiction.

It is noteworthy that only 13 federations (14\%) out of 95 CPFs those ventured into the production have continued their activities (Table $2)$. In eight out of 14 districts, the 'neera' production by CPFs had ceased. It was revealed that the initial phase of production and marketing activities were encouraging wherein the CDB had provided adequate support to the entrepreneurs.
As they have entered the subsequent phase, CDB has curtailed their active support in a phased manner, and the FPOs were unable to cope with the production and market-related hurdles emerged after that, which ushered most of them, the exit routes.

The scarcity of skilled human resources for 'neera' tapping coupled with very high wage rate, was observed to be the major factors attributed towards the discontinuance of 'neera' production (Table 3). The handholding provided by CDB has been withdrawn sooner, which also had detrimentally affected the confidence of the entrepreneurs. The supply chain of 'neera' was not robust enough to sustain the activities with the optimal distribution of revenue share. The respondents were unequivocal about the low level of technical knowledge, and marketing expertise of the entrepreneurs ventured into the 'neera' sector.

The CDB, during the initial stages, vigorously supported CPFs and provided incentives for the production and marketing of 'neera'. Apart from facilitating CPFs and CPCs in these activities, CDB also promoted a private-sector $\mathrm{R} \& \mathrm{D}$ institution to develop technology for neera production 
(Chinnamma et al., 2019). It was projected that the income of coconut growers would be increased by manifold if value addition units to produce and market 'neera' were established by the coconut growers (Jose, 2013). Though the pro-active measures by $\mathrm{CDB}$, in the beginning, were quite encouraging, the CPFs perceived that enough support was not extended by $\mathrm{CDB}$, especially when they started facing various constraints to pursue the 'neera' based activities. According to them, the lack of continued support was an important reason for the discontinuance of 'neera' production activities. Planning and implementation of interventions on production and marketing of 'neera' were mostly done with a general format prescribed by CDB. In contrast, the majority of coconut FPOs was not having a clear perspective of managing the 'neera' enterprise on their own. The asymmetry of information on the level of inherent managerial and technical expertise of the FPOs was the major reason for early discontinuance of 'neera' business by the aspirants.

It is a startling fact that State Department of Agriculture Development and Farmers' Welfare with the vast network of extension system that includes Krishibhavans at grass root level in every gramapanchayat was not involved in the formation of three-tier FPO system in coconuts. Furthermore, the coconut development schemes of the Department of Agriculture were implemented with a separate mechanism of farmers' participation without utilizing the existing platform of CPS, CPF and CPC structure of FPOs. This lack of coordination among the governmental agencies has failed in harnessing the synergy for effective management of 'neera' enterprises.

\section{i. Labour related constraints}

Scarcity of palm climbers/ 'neera' technicians was observed to be an important factor that had adversely affected the sustenance of 'neera' enterprises in the State. The predominance of tall coconut palms in the coconut orchards in the State was another limiting factor that added to the workload of climbers engaged in 'neera' tapping. Commitment from skilled climbers is a key factor in the successful management of 'neera' enterprise and in many units lack of punctuality of climbers and conflicts over the wage rate created difficulties in ensuring regular supply of the product.

\section{ii. Technology related constraints}

Lack of product uniformity due to nonstandardized technologies for 'neera' collection across the State was another important reason perceived by CPFs for the discontinuance of 'neera' enterprise. Spoilage due to low keeping quality of this product was also cited as another reason for discontinuance. The study revealed that majority of the CPFs (73\%) adopted technology developed by CDB through the private R\&D firm, for 'neera' collection and processing and the remaining 27 per cent CPFs resorted to technology developed by ICAR-CPCRI. The technology developed by CPCRI involves the collection of 'neera' using 'coco sap chiller' followed by freezing at $-28^{\circ} \mathrm{C}$. The 'neera' thus collected, named as 'Kalparasa' by the Institute, is promoted as a fresh health drink and not recommended for boiling because once the 'neera' is exposed to thermal treatment above $60^{\circ} \mathrm{C}$ as part of pasteurization for bottling, the natural flavour of the product is lost. This specificity of the technology limits its commercial exploitation through scaling up the production. In the technology developed by CDB, an AntiFermentation Solution (AFS) is added into the 'neera' collecting vessel during tapping. After that, the collected product is transferred to iceboxes and is transported to the processing plant where it is subjected to high-speed centrifugation, microfiltration, pasteurization and packaging in sealed bottles/containers. Interventions were not carried out by the agencies for pilot testing of 'neera' collection technologies for assessing their effectiveness and refinement of technologies to suit the techno-socio-economic requirements for further scaling up production and marketing and comparing the available technologies on different attributes for making target specific recommendations. Lack of back up support for effective field-level utilization of 'neera' technologies by the concerned agencies was thus cited as another problem by the CPFs. 


\section{iii. The economic viability of the 'neera' enterprise}

Even though a very attractive level of economic benefit was projected for the enterprises of neera, due to field level constraints, it could not be realized in reality. It was highlighted that if 10 per cent of the coconut palms in Kerala were used for 'neera' tapping it would create direct employment opportunities for 10 lakh people and coconut farmer can earn a minimum of ₹ $1200 /-$ per coconut palm per month (Chandrasekhar, 2013).

The 'neera' collection was limited to 100 coconut palms by the majority of CPFs (78\%), 100 to 200 palms by 13 per cent CPFs, 200 to 300 palms by two per cent CPFs, 300 to 400 palms by three per cent CPFs, 400 to 500 palms by two per cent CPFS and above 500 palms by two per cent CPFs (Table 4). The existing policy on 'neera' production has prevented the CPFs from the realization of economies of scale.

Table 4. Number of coconut palms utilized for 'neera' production by CPFs

\begin{tabular}{cc}
\hline $\begin{array}{l}\text { No. of palms used } \\
\text { for 'neera' tapping }\end{array}$ & No. of CPFs \\
\hline $1-100$ & 74 \\
$101-200$ & 12 \\
$201-300$ & 2 \\
$301-400$ & 3 \\
$401-500$ & 2 \\
$>501$ & 2 \\
\hline Total & 95 \\
\hline
\end{tabular}

Source: A field study on CPFs

Similarly, it was revealed that CPFs covered only a minuscule of coconut orchards under the 'neera' production initiative (Table 5).

Table 5. Coconut gardens covered under 'neera' production initiative by CPFs

\begin{tabular}{lcc}
\hline $\begin{array}{l}\text { No. of coconut } \\
\text { gardens covered }\end{array}$ & No. of CPFs & Percentage \\
\hline Up to 10 & 62 & 65 \\
$11-20$ & 17 & 18 \\
$21-40$ & 10 & 11 \\
$41-100$ & 4 & 4 \\
Above 100 & 2 & 2 \\
\hline Total & 95 & 100 \\
\hline
\end{tabular}

Source: A field study on CPFs
Table 6. The average yield of 'neera' per palm per day of tapping

\begin{tabular}{lcc}
\hline $\begin{array}{l}\text { Quantity of } \\
\text { 'neera' per palm } \\
\text { per day (litres) }\end{array}$ & No. of CPFs & Percentage \\
\hline $0-1$ & 1 & 1 \\
$1-2$ & 30 & 32 \\
$2-3$ & 31 & 33 \\
Above 3 & 33 & 35 \\
\hline Total & 95 & 100 \\
\hline
\end{tabular}

Source: A field study of CPFs

The average yield of 'neera' per palm per day of tapping varied widely among coconut orchards covered by CPFs (Table 6).

Out of 95 respondents (CPFs), it was found that one CPF realized a very low average yield of one litre or less 'neera' per palm per tapping day. The remaining CPFs were divided into almost three equal groups $(32 \%, 33 \%$ and $35 \%)$ obtaining yield levels of 1-2 litres of 'neera' per palm per day, 2-3 litres, and above three litres per palm per day.

\section{iv. Marketing related constraints}

Problems related to marketing were perceived as another major hurdle in sustaining 'neera' enterprise by CPFs. Lack of product uniformity was also an important reason adversely affecting market penetration as perceived by CPFs. Some of the CPFs felt that 'neera' technicians were not quite efficient in following the production protocol recommended, which adversely affected the product quality. Consumer perception studies which are essential for streamlining strategies for successfully marketing a product were not made before launching the commercial 'neera' production and marketing initiatives. 'Neera' enterprises under coconut FPOs were finding it difficult to handle the competition with other products including soft drinks for the market share and 'neera' as a unique product with nutritional edge was not appropriately positioned in the market. During the rainy season, 'neera' tapping was not regular due to difficulty in palm climbing, and hence CPFs could not ensure regular supply of the product in the market.

Coconut producer companies mostly manage the marketing of 'neera'. Outlets under CPCs and 
CPFs, sales opportunities in exhibitions, and other sales outlets including local shops, bakeries and supermarkets were utilized for marketing of 'neera'. According to few CPFs, pricing of 'neera' was not appropriate; 'neera' was sold at the rate of ₹ 150 per litre which was on the higher side compared to the price of soft drinks, the competing products. Analysis of the revenue distribution in 'neera' value chain revealed that coconut farmer received 17 per cent of the consumer price. In comparison, the tapper got 20 per cent share that sums up to 37 per cent total value share in the upstream end (production node). The remaining share of revenue was received by FPOs (CPFs and CPCs) to meet the operational costs.

\section{Support mechanism to enable FPOs to sustain production and marketing of 'neera'}

The techno-socio-economic analysis of interventions on 'neera' by the FPOs in coconut sector and the field level scenario of their sustenance indicate the need for a restructured support mechanism to enable them to carry out their activities effectively. Based on the results of the study, a framework for the same is suggested as follows (Table 7).

The beneficial impact of the restructured support mechanisms on the sustainability of activities of coconut FPOs in Kerala, the pioneer in institutionalizing interventions on 'neera' for improving livelihoods of coconut growers, would be useful for the FPOs in neighbouring States of Karnataka, Tamil Nadu and Andhra Pradesh to streamline their activities where similar 'neera' based enterprises are coming up with an enabling policy environment and incentive mechanisms.

\section{Way forward}

Though the Government of Kerala has come out with a pro-farmer policy frame for the production and promotion of 'neera' in the State, it is highly paradoxical that still, the product is partially under the control of Excise Department, wherein they are entrusted with granting the license for the 'neera' production. The producer organizations perceive it as a cumbersome process to obtain the license for tapping coconut palms for 'neera' and renewal of the license every year. They also perceived that 'neera' being promoted as a non-alcoholic health drink, should be delinked from the Excise Department to make the formalities for issuing license simpler. Further, it was suggested that the Department of Agriculture and Farmers' Welfare should assume more responsibilities in the promotion and regulation of 'neera' based activities through the FPOs. The perceptions evolved in this regard indicate the need for revisiting policy on 'neera' for empowering the FPOs in the sector to sustain their activities.

Table 7. Institutional frame to strengthen the 'neera' innovation system

\begin{tabular}{lll}
\hline $\begin{array}{l}\text { Sl. } \\
\text { No. }\end{array}$ & Activity & Agency responsible \\
\hline 1. & $\begin{array}{l}\text { Revisiting policy on 'neera' production } \\
\text { and marketing and removal of ceilings }\end{array}$ & State Government \\
2. & $\begin{array}{l}\text { Technology standardization and ensuring } \\
\text { product uniformity }\end{array}$ & ICAR-CPCRI, KAU, CDB \\
3. & Conducting market studies & ICAR-CPCRI, KAU, CDB \\
4. & Assured availability of 'neera' technicians & $\mathrm{CDB}$, State Department of Agriculture, FPOs \\
5. & Publicity and product positioning & $\mathrm{CDB}$, State Department of Agriculture, FPOs \\
6. & Organized marketing & $\mathrm{CDB}$, FPOs, State Government \\
7. & Institutional support to FPOs & $\mathrm{CDB}$, State Department of Agriculture, LSGs \\
8. & Co-ordinating stakeholders and interventions & $\mathrm{CDB}$, State Department of Agriculture \\
\hline
\end{tabular}


The yield of inflorescence sap mainly depends on palm health, and it is imperative to maintain well-nurtured coconut palms to ensure the better yield of 'neera'. Hence, scientific management of coconut palms plays a crucial role in ensuring better yield and continuous supply of 'neera' in the upstream end (production node) of the value chain.

A well designed, target specific entrepreneurial development programme on various facets of 'neera' value chain would have helped the business aspirants to endure the inertia of business in the initial phase. Hence, this episode of early discontinuance of 'neera' production and marketing by the FPOs provides a corrective lesson that has to be incorporated in the revamped policy document on 'neera' sector.

Functional linkages among various stakeholders in the 'neera' innovation system must be strengthened with defined roles for enhancing profitability and sustainability. It is of utmost importance to increase the value share in the production node by possible integration of the chain or up-gradation in the chain.

Effective coordination of activities and functional linkages among research institutions including CPCRI, KAU, the research agencies in the private sector, $\mathrm{CDB}$, the State Department of Agriculture and FPOs in coconut sector are prerequisite for assessment and refinement of 'neera' production technologies to suit the field level requirements for scaling up.

\section{Conclusion}

Value addition through product diversification was suggested as an important strategy for enhancing income from coconut farming which is dominated by small and marginal farmers having resource limitations. After the policy shift favouring production and marketing of 'neera', the coconut inflorescence sap which is a value-added product promoted as a health drink, a large number of producer organizations in coconut sector were facilitated to start 'neera' based enterprises for income and employment generation. The CDB supported these producer organizations through various incentives. The study revealed that a substantial number of producer organizations could not sustain their activities due to various constraints, including technology-related, marketing-related and policy-related issues. Results of the study indicated the need for a restructured support mechanism to sustain the FPOs to effectively carry out activities related to 'neera' based enterprises.

\section{References}

Chandrasekhar, K.M. 2013. Keralathinte karshikasampathvyavasthakkuoorjampakaranneera (in Malayalam).Indian Nalikera Journal 4(5): 4-6.

Chinnamma, M., Bhasker, S., Binitha Hari, M., Sreekumar, D. and Madhav, H. 2019. Coconut neera - a vital health beverage from coconut palms: Harvesting, processing and quality analysis. Beverages 5(1): 22.

Coconut Development Board 2020. https://coconutboard. nic.in/. Ministry of Agriculture and Farmers Welfare, Govt. of India.

Gulati, A. and Juneja, R. 2019. Agricultural credit system in India: Evolution, effectiveness and innovations. Working Paper 184.Center for Development Research, University of Bonn. 56p.

Hebbar, K.B., Arivalagan, M., Manikantan, M.R., Mathew, A.C., Thamban, C., Thomas, G.V. and Chowdappa, P. 2015. Coconut inflorescence sap and its value addition as sugar - collection techniques, yield, properties and market perspective. Current Science 109(8): 1411-1417.

Hellin, J. and Camacho, C. 2017. Agricultural research organizations' role in the emergence of agricultural innovation systems. Development in Practice 27(1): 111-115.

Jayasekhar, S, Chandran, K.P., Thamban, C. and Muralidharan, K. 2019. Coconut sector in India experiencing a new regime of trade and policy environment: A critical analysis. Journal of Plantation Crops 47(1): 48-54.

Jnanadevan, R. 2016. Rubber Producer Societies - Extension and development arms of Rubber Board. In: Innovative Extension Approaches for Plantation Crops. (Eds.) Thamban, C., Jaganathan, D., Anithakumari, P., Kalavathi, S., Chandran, K.P. and Jayasekhar, S., Kasaragod. pp. 32-36.

Jose, T.K. 2013. Neerayumkeravum Keralavum (in Malayalam). Indian Nalikera Journal 4(5): 2-3.

Lijo.T., Rajeev, P. and Sanal, P.C. 2017. Promise and prospects of farmer producer organizations: The Kerala experience. Indian Journal of Agricultural Marketing 30(2): 1-10. 
Thamban, C., Subramanian, P. Jayasekhar, S., Jaganathan, D. and Muralidharan, K. 2016a. Group approach for enhancing profitability of smallholders through technology integration - Reflections from coconut farming. Journal of Plantation Crops 44(2):158-165.

Thamban, C., Jayasekhar, S., Chandran, K.P., Jaganathan, D. and Jesmi Vijayan. 2016b. Evolving sectoral innovation system of 'Neera': The apprehensions, potential, and strategies. In: Abstracts-3 ${ }^{\text {rd }}$ International Symposium on
Coconut Research and Development, (Eds.) Chowdappa, P., Muralidharan, K., Samsudeen, K. and Rajesh, M.K., ICAR-CPCRI, Kasaragod, Kerala, India. pp.46.

Trebbin, A. (2014). Linking small farmers to modern retail through producer organizations - Experiences with producer companies in India. Food Policy 45: 35-44.

Trebbin, A. and Hassler, M. 2012. Farmers' producer companies in India: a new concept for collective action. Environment and Planning 44(2): 411- 427. 